\title{
Symposium review: Selection for fertility in the modern dairy cow- Current status and future direction for genetic selection*
}

\author{
M. C. Lucy† \\ Division of Animal Sciences, University of Missouri, Columbia 65211
}

\section{ABSTRACT}

The establishment of pregnancy following insemination is the primary definition of fertility in most dairy systems. Highly fertile cows establish pregnancy sooner after calving and require fewer inseminations than lower-fertility cows. Pregnancy occurs through a series of individual events in sequence. In postpartum cows, for example, the uterus involutes, estrous cycles are re-established, estrus is expressed and detected, sperm are deposited in the reproductive tract and capacitate, ovulation occurs and is followed by fertilization, and the corpus luteum forms and produces sufficient progesterone to maintain pregnancy. The oviduct supports early cleavage and the uterus establishes a receptive environment for the developing pregnancy. Each individual event is theoretically heritable and these events collectively contribute to the phenotype of pregnancy after insemination. Across most dairy systems, genetic selection for fertility in cows is primarily based on reduced days from calving to pregnancy (i.e., days open). Dairy systems differ with respect to reproductive management applied to cows, which may affect the relative importance of individual components to the overall fertility of the cow. In some systems, cows are inseminated after detected estrus with minimal intervention. In these systems, days open effectively captures the summation of the individual components of fertility. More intensive systems use hormonal treatments (e.g., $\left.\mathrm{PGF}_{2 \alpha}, \mathrm{GnRH}\right)$ followed by timed artificial insemination (AI). Timed AI does not invalidate days open but the individual components that contribute to days open may be more or less important. Selection of cows for days open within populations that are managed differently may place different pressures on the individual components of fertility. Ensuring uniform performance of future cows across a variety of reproductive manage-

Received August 11, 2018.

Accepted November 16, 2018.

* Presented as part of the Breeding and Genetics Symposium: Fertility - Filling the Gaps at the ADSA Annual Meeting, Knoxville, Tennessee, June 2018.

†Corresponding author: lucym@missouri.edu ment systems may require a greater understanding of the underlying genetics of the individual components of fertility.

Key words: genomics, fertility, selection, phenotypes

\section{INTRODUCTION}

Dairy cow selection indices have changed markedly in the past 25 yr. Until 1994, very few dairy selection indices contained traits other than total milk fat and protein production (Cole and VanRaden, 2018). This selection strategy was highly effective in creating the high-production dairy cows that comprise the modernday population (Miglior et al., 2017). Negative genetic correlations between production and fertility, however, led to a progressive decline in dairy cow fertility (Berry et al., 2014). The poor fertility of dairy cows created a temporary crisis in the industry (Lucy, 2001). Today, none of the modern selection indices used globally are based solely on milk fat and protein production; milk production traits typically comprise approximately $50 \%$ of the total index (Cole and VanRaden, 2018). In addition to milk production traits, modern indices incorporate functional traits, including those that are specifically designed to improve reproductive performance (Miglior et al., 2017; Cole and VanRaden, 2018; Pryce et al., 2018). This change in dairy selection indices has reversed the decline in reproductive traits as well as other important functional traits in dairy cattle (Carvalho et al., 2018; Cole and VanRaden, 2018). The combination of improved reproductive management and improved genetics has greatly improved on-farm reproduction (Wiltbank and Pursley, 2014; Carvalho et al., 2018; Cole and VanRaden, 2018).

Genomic selection combined with advanced reproductive technologies has accelerated the rate of genetic progress in dairy cows (Bouquet and Juga, 2013; Thomasen et al., 2016). This is feeding an "arms race" in dairy genetics between nations and among the companies that provide semen for AI. Current selection indices are heavily weighted toward the healthy and productive cow so the rapid rate of improvement is welcome. Rapid progress can lead to unexpected outcomes, 
however, that should be considered sooner rather than later in the process. This review will present (1) the individual components of dairy cow fertility; (2) how present-day fertility traits address the individual components; (3) implications of different management systems to genetic selection for fertility; and (4) new fertility traits that might be amenable to genetic selection. A final section will present challenges, knowledge gaps, and future research directions.

\section{INDIVIDUAL COMPONENTS OF DAIRY COW FERTILITY}

Dairy cow fertility can be scored as "all or none" (the cow either births a calf or does not following insemination) and this is the basis for most fertility traits. But this all-or-none phenomenon is a composite of a series of events, all of which must occur successfully in sequence (Lucy, 2003, 2007; Figure 1).

\section{Uterine Involution}

For cows, the process leading to the establishment of the next pregnancy begins with the birth of a calf and the initiation of lactation. A calving that is free from trauma and disease is essential for subsequent reproductive success. Dystocia and (or) uterine disease (metritis), including retained placenta $(\mathbf{R P})$, at the time of calving is experienced by 10 to $20 \%$ of cows (Gilbert, 2016). Metritis with or without RP typically leads to subclinical endometritis (SCE), a uterine disease that is found later postpartum (Wagener et al., 2017). Postpartum uterine disease has long-term effects on the subsequent establishment of pregnancy (Carneiro et al., 2016; Ribeiro et al., 2016). The inability of the cow to resolve uterine disease may be explained in part by immune dysfunction early postpartum that is caused by a metabolic profile that antagonizes the innate immune system (Contreras et al., 2018; Sheldon et al., 2018).

\section{First Ovulation Postpartum}

Ovulation within the first month postpartum is favorable for reproductive success (Galvão et al., 2010). The interval to first ovulation is largely dependent on the endocrinology of the cow [ $\mathrm{LH}$ pulsatility and growth factor (insulin and IGF1) concentrations] that is largely determined by energy balance early postpartum (Lucy, 2003). Cows in extreme negative energy balance and losing weight have low LH pulsatility and growth factor concentrations that are partly explained by the uncoupling of the somatotropic axis (Lucy et al.,
2001). Failure to recouple the somatotropic axis leads to low BCS, low growth factor concentrations, low LH pulsatility, and anovulatory anestrus (Wiltbank et al., 2002).

\section{Estrous Cyclicity}

The first postpartum estrous cycle may be shorter in length, which is considered normal, but afterward cycles are approximately $21 \mathrm{~d}$ long (Crowe, 2008; Remnant et al., 2015). Although the expectation is that cows will have 21-d cycles, most studies have found that over one-quarter of postpartum estrous cycles are "irregular" (Lamming and Darwash, 1998; Petersson et al., 2006; Nyman et al., 2014). Irregular estrous cycles include prolonged interval to first ovulation after calving, longer than normal follicular phases (failure to ovulate a follicle after regression of the corpus luteum, CL) or longer than normal luteal phases (extended lifespan of the CL beyond the typical 15 to $18 \mathrm{~d}$ ). In any of the aforementioned cases, the expected pattern of the estrous cycle is disrupted and the assumptions for ovarian function are not met. Cows with atypical estrous cycles are difficult to manage because they return to estrus at irregular intervals and have lesser fertility postpartum (Petersson et al., 2006; Ranasinghe et al., 2011).

\section{Steroid Concentrations During the Estrous Cycle}

Progesterone. In addition to irregularities in estrous cyclicity, there is the potential for abnormally low circulating progesterone during the luteal phase in lactating cows. The high feed intake and highly metabolic state required to support lactation are associated with the rapid degradation and clearance of steroid hormones in liver (Wiltbank et al., 2006). Steroid clearance reduces circulating progesterone concentrations. The developing embryo is dependent on progesterone through the action of progesterone on uterine histotroph secretion (Spencer et al., 2016). Low concentrations of progesterone may reduce the growth of the embryo (Lonergan, 2011). A poorly developed embryo may fail to signal the mother within the required window for maternal recognition of pregnancy (approximately 14 to $18 \mathrm{~d}$ after breeding; Forde and Lonergan, 2017). Failure to signal leads to early embryonic death because the uterus does not recognize the pregnancy (Wiltbank et al., 2016).

Estradiol. Behavioral estrus is dependent on sufficient circulating estradiol (Woelders et al., 2014). Lactating cows that fail to express estrus or have poor estrus expression may do so because there is insufficient circulating estradiol during the preovulatory period 


\section{Hypothalamus/Pituitary \\ Estrus, GnRH/LH surge, FSH}
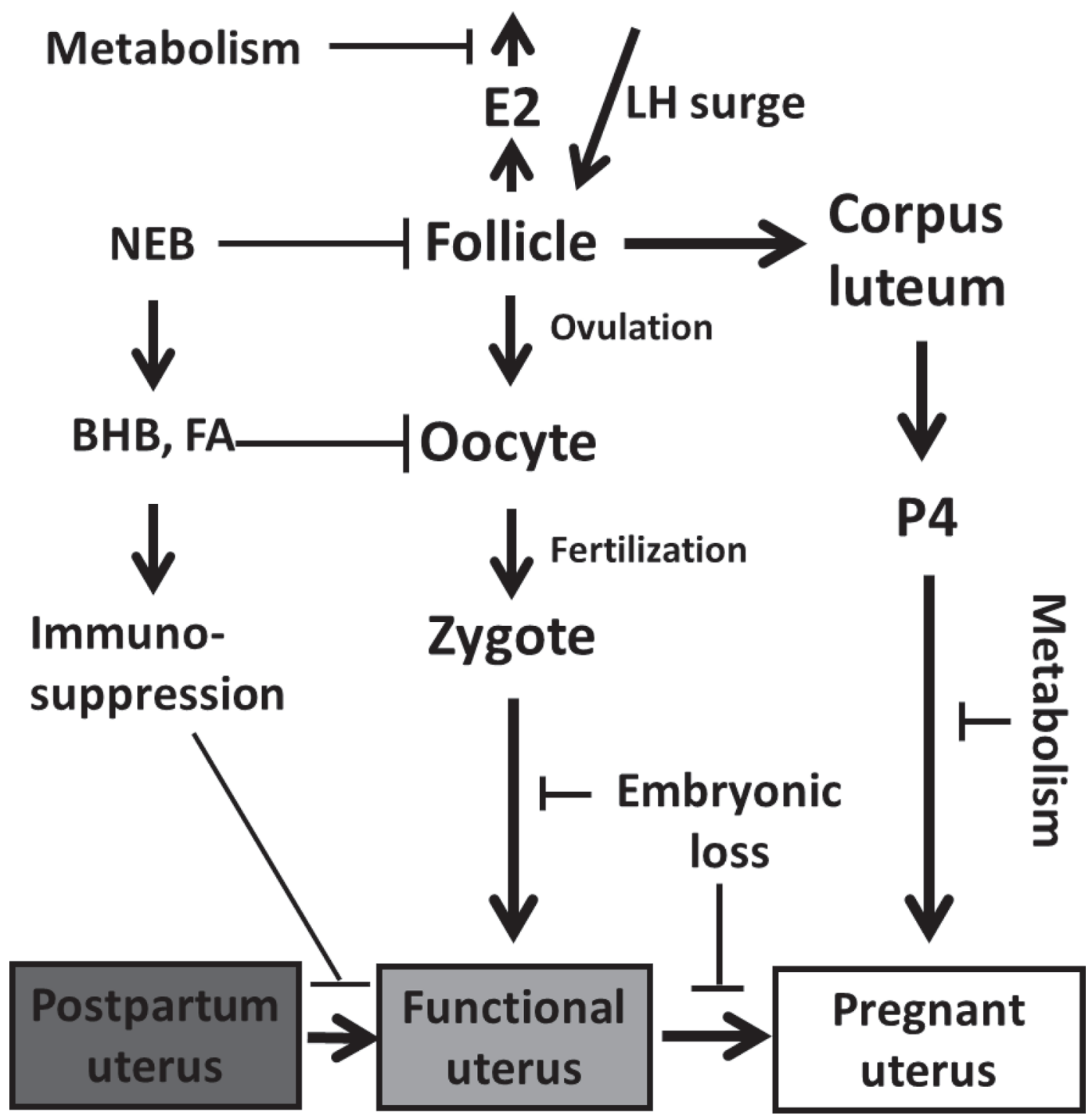

Figure 1. Key components of fertility in the lactating dairy cow. The follicle synthesizes and secretes estradiol (E2) that controls the expression of estrus and the LH surge, causing ovulation. The oocyte is released and fertilized in the oviduct, forming the zygote. The corpus luteum forms from the ovulated follicle and synthesizes and secretes progesterone (P4). The postpartum uterus undergoes involution during the first 30 to $60 \mathrm{~d}$ postpartum and becomes functional. Negative energy balance (NEB) creates an endocrine milieu that slows the growth of the follicle and reduces functionality. The NEB also increases circulating BHB and fatty acids (FA), which reduce the fertility of the oocyte and cause immune dysfunction. The immune dysfunction inhibits the recovery of the uterus and prolongs the period of uterine inflammation. High feed intake in high-production cows causes liver metabolism of both E2 and P4 that can reduce circulating concentrations and affect endocrine axes controlling the estrous cycle and the development of the pregnancy.

(Cavalieri et al., 2006; Woelders et al., 2014). Lesser circulating estradiol in lactating cows is believed to be caused by a poorly developed preovulatory follicle, a high rate of steroid clearance, or both (Lucy, 2003; Wiltbank et al., 2006).
Estradiol also plays a role in determining the luteal phase because estradiol causes uterine $\mathrm{PGF}_{2 \alpha}$ release and the upregulation of uterine oxytocin receptors required for luteolysis (Hansen et al., 2017). A high rate of steroid clearance or reduced capacity of estradiol 
synthesis by the follicle may lead to a failure in luteolytic mechanisms and cycle length extension. A similar mechanism may apply to delayed ovulation where the follicle is unable to generate sufficient circulating estradiol concentrations to cause estrus and the LH surge (Lucy, 2003). Replacing the dominant follicle with a new follicle requires about $7 \mathrm{~d}$ and hence a delay in the time from luteolysis to ovulation (delayed ovulation).

Low estradiol concentrations may contribute to the high incidence of double ovulation and twinning in dairy cows (Wiltbank et al., 2000). Estradiol feeds back negatively on FSH during the follicular phase. Absence of sufficient estradiol leads to elevated FSH, which drives an additional follicle through selection and ovulation. The additional oocyte may be fertilized to create a twin pregnancy, which is undesirable in dairy production (Macmillan et al., 2018).

\section{Oocyte Quality}

In addition to its role in estradiol biosynthesis, the follicle also houses the oocyte and enables its growth and development. The highly catabolic environment of the early postpartum cow is associated with high circulating concentrations of BHB and fatty acids that may imprint the oocyte and reduce its fertility (Leroy et al., 2011). There is also the potential for bacterial toxins arising from the diseased uterus to cause inflammation within the ovary and reduce oocyte competence (Bromfield et al., 2015; Ribeiro et al., 2016). Shorten et al. (2018) reported that approximately $65 \%$ of inseminated dairy cows had a viable embryo 1 wk after AI (Shorten et al., 2018). The low percentage of pregnant cows $1 \mathrm{wk}$ after AI is perhaps explained by a low-quality oocyte with fertilization failure or poor developmental competence within the oviduct during the first week after AI.

\section{Pregnancy Maintenance}

Most cows undergo an initial pregnancy exam at approximately $32 \mathrm{~d}$ after AI. Approximately $10 \%$ of cows pregnant on d 32 will lose their pregnancies before d 60 (Wiltbank et al., 2016). One cause of embryonic loss between d 32 and 60 may be scarring and inflammation within the uterus that arises from early postpartum uterine infection and affects the capacity of the embryo to develop during the second month of pregnancy (Lucy et al., 2016).

\section{CURRENT SELECTION STRATEGIES}

The ultimate goal is for the cow to produce a calf at some desired interval. This may be annually $(12 \mathrm{mo})$ in seasonal (pasture-based) systems or slightly longer than a year in year-round calving systems (cows in confinement). Genetic selection for fertility is based on different traits. The traits may address different components of dairy cow fertility (Figure 1). For example, metritis resistance addresses the recovery of a healthy uterus, and interval to first postpartum estrus addresses the reestablishment of ovarian cycles postpartum. Other traits capture several components of the pathway. Days open (DO), for example, captures a series of events that enable the cow to establish and maintain the pregnancy. Some traits are not technically considered fertility traits but are positively correlated with DO, particularly those related to longevity (the genetic correlation of productive life with DO, for example, is 0.59; VanRaden et al., 2004). Examples of traits that address specific components of fertility are discussed in this section.

\section{Uterine Health}

The introduction of new traits for disease resistance is an important step in creating a healthy uterus, which will improve fertility (Neuenschwander et al., 2012; Parker Gaddis et al., 2014; Vukasinovic et al., 2017). Genetic correlations between metritis and DO, for example, were 0.25 for Canadian Holsteins, indicating a measurable benefit to interval to pregnancy in cows with less metritis (Neuenschwander et al., 2012). Traits relating to the calving process (calving ease and stillbirth) ultimately affect uterine health postpartum because cows with difficult calvings are more likely to have RP and (or) contract metritis (Beagley et al., 2010). Cows that birth twin calves also have a greater risk for dystocia, RP, and metritis (Komisarek and Dorynek, 2002). Direct selection against twin pregnancies, therefore, could improve fertility through a mechanism involving improved uterine health postpartum.

The cow's immune system is primarily responsible for resolution of disease and recovery from inflammation within the uterus postpartum (Contreras et al., 2018; Sheldon et al., 2018). The low circulating glucose and elevated circulating BHB that are found during early lactation can antagonize circulating immune cell function (Lucy et al., 2014). Genetic correlations between ketosis and metritis are approximately 0.2 (Pryce et al., 2016). This relationship may represent a direct inhibitory effect of elevated BHB on the cow's immune system that leads to immune dysfunction and an inability to resolve uterine disease. Selecting against ketosis may improve fertility through overall effects on immune function and cow health. Direct selection of cows for improved immune function may also contribute to im- 
proved health postpartum and reduce the incidence of metritis (Mallard et al., 2015).

\section{Interval to First Insemination}

Direct selection for interval to first insemination or interval from planned start of mating to first insemination (seasonal herds) theoretically improves ovarian function through its effects on the systemic endocrinology of the cow. Dairy cows typically begin cycling within the first month after calving (Galvão et al., 2010) but negative energy balance can dampen LH pulsatility and growth factor concentrations so that dominant follicles do not fully mature and cows do not ovulate (Lucy, 2003). Interval to first insemination has 2 components - the initiation of cyclicity and the expression of estrus by the cow. Estrus expression is an indication that the cow is cycling and that the follicle is producing sufficient estradiol to cause estrus expression (Woelders et al., 2014). In the absence of intervention, interval to first insemination effectively captures the phenotype of a healthy ovary early postpartum. A related trait - interval from planned start of mating to insemination - places additional selection pressure against late-calving cows in seasonal systems (Bowley et al., 2015). Selecting for a shorter gestation length may have economic value in seasonal herds through its effects on calving interval and ensuring earlier calving in cows that become pregnant late in the previous breeding season (Jenkins et al., 2016).

Disease can affect feed intake either directly or indirectly through pain, fever, or both, and their effects on appetite (Potter et al., 2018). Diseased cows with poor feed intake postpartum and healthy cows with poor appetite will lose excess BCS and have an endocrine, metabolic, and immune profile that antagonizes ovarian cyclicity postpartum (Lucy, 2003; Butler, 2014). Selecting for greater BCS in postpartum cows, as is practiced in New Zealand, will improve fertility through a mechanism that may involve an earlier return to cyclicity in postpartum cows (Dechow et al., 2002; Pryce and Harris, 2006; Roche et al., 2009). We observed a change in the shape of the lactation curve for highly fertile New Zealand cows compared with less fertile North American cows on grass pasture (Lucy et al., 2009). The change in the shape of the lactation curve enabled less dependence on early postpartum BCS loss in New Zealand cows. The lesser loss in BCS theoretically translated into greater fertility postpartum. New electronic systems that capture BCS on farm should make it possible to efficiently phenotype cows for BCS (Figure 2) and perform direct selection for the BCS trait.
Genetic selection for fertility in the future will be done without a predetermined notion of what effect it will have on the cow (beyond the improvement in fertility). One possibility is that further selection for fertility and productivity will lead to cows whose reproductive system can function well regardless of the postpartum change in BCS or other metabolic changes associated with peak lactation yield. In this scenario, reproductive success does not depend on either the metabolic status of the animal or the BCS. Bauman and Currie (1980) illustrated the prioritization of reproductive function during weight loss by using the example of salmon migrating to spawning grounds upstream. In these species, the reproductive system matures while the fish loses weight during migration.

\section{Estrous Cycles and the Establishment of Pregnancy}

The ability of a cow to establish and maintain pregnancy is a reasonable indication of a healthy uterus and a functional CL. Cows that are cycling as they enter the breeding period will be inseminated if they show signs of estrus (Wiltbank et al., 2002; Galvão et al., 2010). The intensity of estrus is thought to be a function of circulating estradiol concentrations, which ultimately arise from the ovarian follicle (Woelders et al., 2014). Fertilization failure or other failure to establish

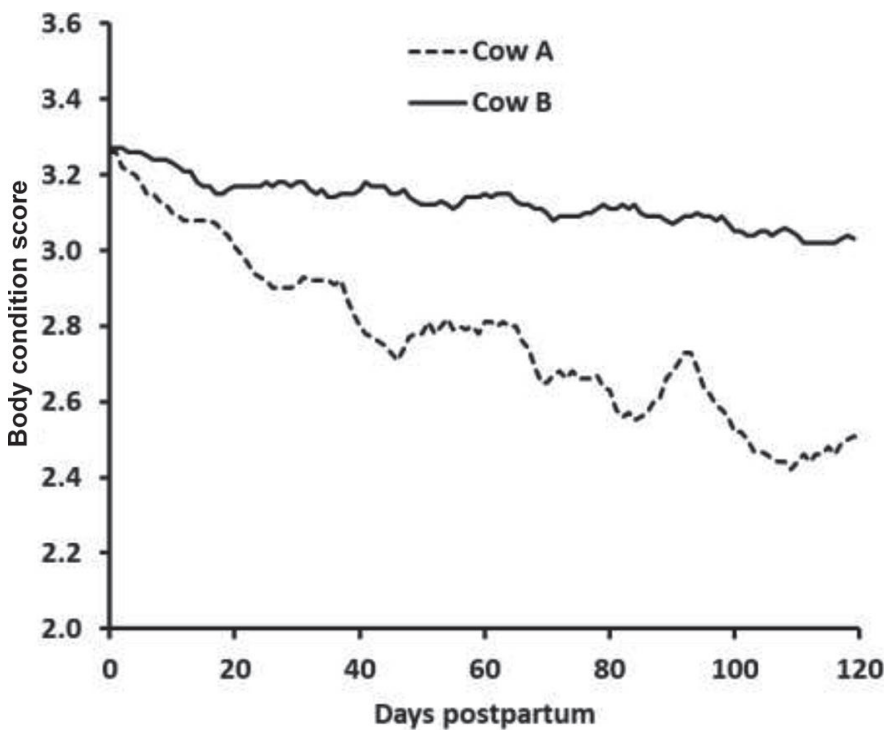

Figure 2. Daily BCS measured on 2 individual cows, A and B, using an automated BCS camera (DeLaval, Tumba, Sweden). Two cows with identical beginning BCS are shown (scale 1 to 5 ; thin to obese). Cow A lost $>0.5$ points during the first $120 \mathrm{~d}$, whereas cow B lost approximately 0.1 point. Selecting against excessive BCS loss early postpartum improves fertility (Dechow et al., 2002). 
pregnancy will result in a return to estrus (Remnant et al., 2015).

"Days open" is the interval from calving to conception and is a common component of fertility traits worldwide (Cole and VanRaden, 2018). In the United States, the trait daughter pregnancy rate (DPR) is used, which is a function of DO (a 1-unit increase in DPR equals 4 fewer DO; VanRaden et al., 2004). Cows with a desirable DO will be cycling, they will express estrus and ovulate in a timely manner (relative to estrus expression), their oocytes will be fertile, and they will form a CL that produces sufficient progesterone. If pregnancy is not established, they will return to estrus within approximately $3 \mathrm{wk}$ and again express estrus so that they can be inseminated. Embryonic loss affects DO because cows that lose pregnancies will have an extended DO, which is not desirable. The DO trait captures most of the genetic variation in interval to first insemination [functional (healthy) ovary] and an additional fertility component; namely, the ability of the cow to establish and maintain the pregnancy.

Both cow conception rate (CCR) and heifer conception rate $(\mathbf{H C R})$ were introduced into the Net Merit selection index in 2014 and after DPR, which was introduced in 2003 (Cole and VanRaden, 2018). The heritability of CCR and HCR is approximately $1 \%$ and considerably less than that of DPR (4\%; VanRaden et al., 2004). The correlation between HCR and CCR is approximately 0.4 (Kuhn et al., 2006), which indicates that some of a cow's fertility during lactation (CCR) is independent of the response to her reproductive system to lactation. Selecting for HCR, therefore, will improve CCR. Age at first calving is a new trait with favorable genetic correlations with $\mathrm{HCR}, \mathrm{CCR}$, and DPR but unfavorable genetic correlations with stillbirth (Hutchison et al., 2017). Reducing the age at first calving will improve some aspects of fertility but may increase the incidence of complications at calving.

\section{Maintenance of Pregnancy}

Uterine disease early postpartum is a risk factor for embryonic loss after breeding (Ribeiro et al., 2013, 2016). Improving the uterine health of cows through genetic selection for resistance to metritis and RP (Neuenschwander et al., 2012; Parker Gaddis et al., 2014; Vukasinovic et al., 2017), therefore, should theoretically reduce the percentage of cows experiencing embryonic loss. Carthy et al. (2015) reported strong genetic and phenotypic correlations between improved uterine health score and reduced embryonic loss. The heritability of embryonic loss was 0.02 (Carthy et al., 2015).
Diseases that cows contract later postpartum during the breeding period can have immediate effects on pregnancy. Cows that experienced mastitis during the breeding period, for example, had lesser fertility (Fuenzalida et al., 2015). Endotoxins from the diseased gland may cause inflammation or $\mathrm{PGF}_{2 \alpha}$ release that aborts the pregnancy. Selecting for a reduced incidence of mastitis, therefore, should improve fertility. The genetic correlation between mastitis resistance and DPR, for example, was 0.2 (Cole and VanRaden, 2018).

\section{IMPLICATIONS OF MANAGEMENT SYSTEMS ON GENETIC SELECTION}

Highly effective reproductive management programs that use timed AI (TAI) have been developed in the past $25 \mathrm{yr}$ (Figure 3). These programs effectively address many of the limitations of the modern dairy cow by controlling the development of follicles and their time of ovulation after insemination (Wiltbank and Pursley, 2014; Carvalho et al., 2018). Current estimates are that approximately $70 \%$ of cows in the United States are treated with a TAI program for first postpartum insemination (Brotzman et al., 2015).

\section{Interval to First Insemination}

Timed AI programs effectively negate the utility of the "interval to first insemination" trait. Cows that are enrolled in TAI programs are inseminated on a given day postpartum, regardless of the functionality of their ovaries (Wiltbank and Pursley, 2014). Countries that include interval to first insemination (or interval from planned start of mating to insemination) in their fertility index should not include data from TAI herds in their genetic evaluations. More modest interventions (e.g., giving $\mathrm{PGF}_{2 \alpha}$ before planned start of mating) introduce noise into the data but do not necessarily invalidate the information. Only cycling cows respond to $\mathrm{PGF}_{2 \alpha}$ and cows will need to be observed in estrus to be inseminated (Lucy et al., 2004). Likewise, treating noncycling cows with progesterone will introduce noise but cows that respond to progesterone treatment and express estrus are generally reproductively superior to those that do not (Lucy et al., 2004).

\section{Days Open and Timed Al}

Without TAI, the DO trait addresses many of the elements that comprise dairy cow fertility. Specifically, cows with regular cycles and sufficient follicular estradiol are more likely to be inseminated - if they release a healthy oocyte and form a CL after ovulation, they will 


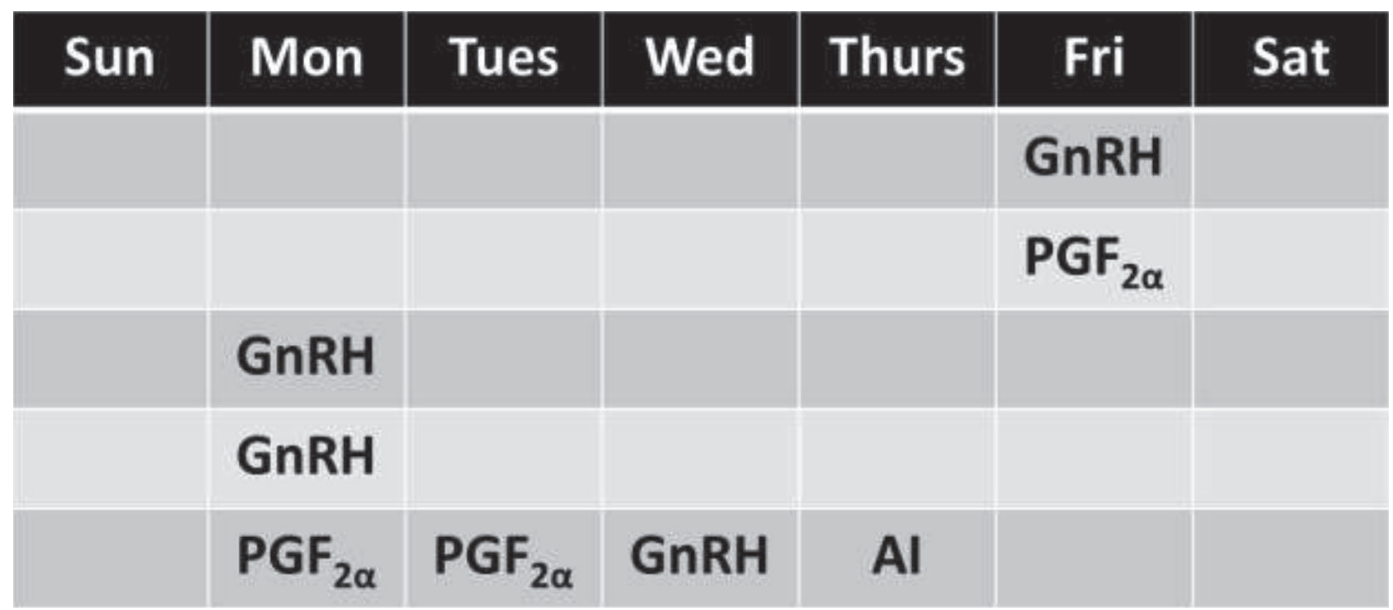

Figure 3. Five-week calendar showing the days for $\mathrm{PGF}_{2 \alpha}$ and $\mathrm{GnRH}$ treatment in a "Double Ovsynch" program for timed AI (Carvalho et al., 2018). Cows are grouped in weekly cohorts and treatments are administered to cohorts on specified days of the week. The sequence of treatments synchronizes the development of the follicle and ovulation so that the insemination (AI) is optimally timed for maximum fertility.

become pregnant. If they fail to become pregnant, then they will return to estrus (sufficient follicular estradiol) and will be observed in estrus. Uterine health is also a component because cows with a healthy uterus are less likely to suffer from infertility and have longer DO.

Timed AI programs do not negate the utility of the DO trait but they do introduce noise into the evaluation. For TAI, follicular waves are synchronized through a series of hormonal injections given during the month leading up to first AI (Figure 3). Prostaglandin $\mathrm{F}_{2 \alpha}$ is given, for example, to regress the CL, and GnRH is given to release $\mathrm{LH}$ and ovulate the follicle (Wiltbank and Pursley, 2014). First AI is scheduled for approximately $60 \mathrm{~d}$ postpartum. It is not necessary for the cow to express estrus before insemination. It is also not technically necessary for the cow to release uterine $\mathrm{PGF}_{2 \alpha}$ to regress the CL or release GnRH in response to estradiol to generate the LH surge. Cows that do not return to estrus and are found to be not pregnant are reenrolled in the system so there is not a requirement for a return to estrus in nonpregnant cows (Carvalho et al., 2018).

\section{Biases Within Data from Timed Al Herds}

Cows enrolled in TAI programs have a distinct advantage compared with non-TAI cows on farm. First insemination for TAI occurs during the first week after the end of the voluntary waiting period (Lucy et al., 2004; Wiltbank and Pursley, 2014; Carvalho et al., 2018). Grouping inseminations with TAI to the first week after the voluntary waiting period biases the interval to first insemination in favor of TAI compared with non-TAI cows that would be expected to have first estrus within the first $3 \mathrm{wk}$ after the voluntary waiting period. Cows that are inseminated and are not pregnant, but fail to return to estrus, are reinseminated at a defined interval when a "resynchronization" program is used for second TAI. The resynchronization prevents extended intervals to second insemination in nonpregnant cows (Carvalho et al., 2018).

The series of hormonal treatments within TAI programs are highly effective in causing luteal regression and ovulation at a known time relative to AI. A misconception is that detection of estrus is $100 \%$ accurate and that cows inseminated "at estrus" are truly in estrus. When examined, nearly $20 \%$ of cows that are recorded as "in estrus" had high progesterone, which indicated that the cow was in the luteal (non-estrual) phase of the cycle (Sturman et al., 2000). Inaccurate detection of estrus leads to inaccurate timing of insemination relative to ovulation. Timed AI programs circumvent problems with detection accuracy and may explain the better fertility in herds that use TAI compared with detection of estrus for AI (Carvalho et al., 2018).

\section{Does Timed Al Change Fertility Evaluations?}

The components of fertility that are theoretically independent of breeding management (TAI or AI after estrus) are those related to oocyte quality, fertilization, formation of the CL, and establishment of pregnancy. These events occur after the TAI program is complete. Genetic selection for DO using data from TAI cows should improve these aspects of fertility. Cyclicity before TAI program initiation (Sterry et al., 2006) 
and estrus expression when insemination is performed (Richardson et al., 2016) have significant positive effects on the overall success of TAI programs. Based on their meta-analysis, Richardson et al. (2016) reported that cows in estrus between $\mathrm{PGF}_{2 \alpha}$ injection and TAI had a $27 \%$ greater conception rate than cows not in estrus (Richardson et al., 2016). Likewise, Sterry et al. (2006) reported a nearly 20-percentage-point greater conception rate after TAI for cycling compared with noncycling cows enrolled in an Ovsynch program. It can be expected, therefore, that although TAI does not depend on estrus or cyclicity, there will be positive selection pressure placed on both when data from TAI cows are used in genetic selection for DO. Most farms will perform a second insemination after observed estrus regardless of whether TAI is used. Cows that are TAI, fail to become pregnant, and return to an observed estrus will have shorter inter-service intervals than cows that are not pregnant, do not express a return to estrus, and are reinseminated after the resynchronization program.

Genetic correlations for fertility traits recorded in different countries are approximately 0.85 (Interbull Center, Department of Animal Breeding and Genetics, Swedish University of Agricultural Sciences, Uppsala, Sweden; www.interbull.org/index). When the same sire is evaluated for DO in the United States (a country where TAI is practiced widely) and Ireland (a country where TAI is practiced minimally), the outcome of the fertility evaluation is largely the same, and there is minimal reranking of sires. Breeding records for herds in the United States have a strong influence of TAI breeding programs but data from Interbull do not support the assertion that genetic evaluation is influenced greatly by regional differences in reproductive management. Nonetheless, the noise introduced by TAI into fertility evaluations could be effectively reduced if the reproductive program were recorded and included in data used for genetic evaluation.

\section{Do Management Systems Dictate the Need for Individual Component Selection?}

Days open is a complex trait that comprises a series of individual components (e.g., uterine health, interval to first ovulation, estrous cyclicity, pregnancy establishment, and maintenance; Figure 1). A complex trait can be improved by selecting for individual components if the components are heritable and the complex trait and the individual component are correlated (Johnson et al., 1985). Selecting for DO does not assume any specific weighting of the individual components of fertility. Selection theory suggests that the most-limiting component of a complex trait will be improved through genetic selection. When pigs are selected for litter size, for example, populations with poor ovulation rate but adequate prenatal survival will respond with an increase in ovulation rate. An alternative population with an excellent ovulation rate and poor prenatal survival will respond with an improvement in prenatal survival (Johnson et al., 1985). In this example, both populations will have an increase in litter size but the underlying mechanism for the genetic improvement differs. Studies of litter size in pigs have also demonstrated that the "natural index" may not yield the optimum weight for the ovulation rate and prenatal survival to achieve the greatest genetic gain (Johnson et al., 1985). If the individual components can be phenotyped (ovulation rate and prenatal survival, for example), then a calculated index based on the individual components may yield faster genetic progress.

In dairy cows, the individual components of the complex trait fertility (defined by DO in this example) may require different weighting to achieve maximal genetic gain in a TAI compared with a non-TAI system. For TAI, there may be little value in the component related to regular cyclicity and expression of estrus because the injections overcome irregular cycles and cows are inseminated irrespective of estrus. Conversely, if TAI is not used, then there is the need to maintain selection pressure on both cyclicity (interval to first ovulation and regular estrous cycles) and the expression of estrus. Moving forward into the future, genetic progress for DO will occur in both systems but the underlying components that dictate genetic progress may differ. This example assumes that the population of non-TAI dairy cows is distinct from the population of TAI dairy cows. This may occur when dairy cows within nations differ with respect to farmer attitudes, veterinary practice laws, management systems, or economics of dairy production (Ireland versus the United States, for example). The trait "days open" in Ireland may not have the same genetic underpinning as "days open" in the United States. This possibility is one rational for the Interbull organization (www.interbull.org).

Consumers may prefer milk from untreated cows, as evidenced by recent experience with the lactation-enhancing hormone recombinant bST (Sax, 2017). Food processors typically react quickly to consumer demands but changes in the underlying genetics of the dairy population may require years of selection. Although TAI cows may achieve similar DO, the relative weight of the underlying components may depend on the treatments used for TAI. The advantage of targeting the individual components of fertility for genetic selection, regardless of the current management system, is that it creates a future cow whose reproductive system is fully functional. Placing selection pressure on follicular development, cyclicity, and expression of estrus, for example, 
could benefit those that practice minimal intervention as well as those that practice TAI because cows that are cycling and express estrus have better performance regardless of the system used. These same cows are resilient to the possibility that the hormones used for TAI will be removed from the marketplace through industry or consumer directives. The disadvantage is that genetic progress is slower because genetic selection is not tailored to the specific production system.

\section{NEW FERTILITY TRAITS}

Genetic selection in the modern era depends on genetic testing (genomics) and accurate phenotyping of individual animals. The collection of accurate phenotypes on a large number of cattle has become the more important consideration for genetic progress. The amount of money invested in phenotyping depends on the value of the trait. Fertility is a complex trait that is a composite of several components (Figure 1). Phenotypes for new traits will need to be collected and evaluated at a cost that is appropriate for their overall effect on fertility and the economics of fertility itself. Current selection for DO, conception rate, longevity, and disease will capture most of the key components of fertility. The traits listed in this section are components of fertility that could be readily phenotyped and possibly used to improve the overall fertility of postpartum cows.

\section{Estrous Cyclicity}

Nyman et al. (2014) examined patterns of estrous cyclicity in research herds based on milk progesterone data across 4 countries (Nyman et al., 2014). They reported that approximately $70 \%$ of cows had normal cycles and $30 \%$ of cows had delayed cyclicity, prolonged luteal phase, or cessation of cyclicity. Lamming and Darwash (1998) and Petersson et al. (2006) also reported approximately $30 \%$ of cows with estrous cycle abnormalities. The estimates of heritability for delayed cyclicity from Nyman et al. (2014) were high (0.24), which agrees with the relatively high heritability for interval to first high activity or interval to first insemination postpartum relative to other fertility traits (Ismael et al., 2015). The heritability of prolonged luteal phases and cessation of cyclicity was close to 0 and these data agreed with Tenghe et al. (2015). Tenghe et al. (2016) used automatic in-line milk progesterone as well as manually assayed milk progesterone to perform a genome-wide association study for progesterone profiles in dairy cows. Their estimates for heritability of a variety of progesterone-based traits, including interval from calving to first luteal activity, ranged from 0.09 to 0.15 . Quantitative trait loci were located on 8 chromosomes. The progesterone-based traits had a greater heritability than calving interval $\left(\mathrm{h}^{2}=0.03\right)$ for study cows. The heritability of inter-luteal interval was low (0.0) which agreed with observations from the study of Nyman et al. (2014) and Tenghe et al. (2015).

The system used by Tenghe et al. (2016) for automated milk progesterone monitoring is used commercially on a large number of cows (Herd Navigator System; DeLaval, Tumba, Sweden; https://www .delaval.com/en-us/our-solutions/herd-management/ herd-navigator/). The system employs an automated milk-sampling device and separate auto-analyzer for progesterone. Cows are sampled based on a biological computer model that determines when to sample so that estrus periods (low progesterone) during the estrous cycle can be identified. Using Herd Navigator, it is possible to identify cows with all of the progesterone traits defined by either Nyman et al. (2014) or Tenghe et al. (2016) (Figure 4). Likely phenotypes for genetic selection would be interval to first ovulation (selecting for shorter interval), length of luteal phase in cycling cows (selecting against both short and long luteal phase length), and inter-luteal interval (selecting against long inter-luteal intervals that indicate that a cycling cow has stopped cycling). Placing appropriate selection pressure on the aforementioned traits should lead to cattle with a regular pattern of estrous cyclicity. These cows would theoretically be simpler to manage because estrus and return to estrus would have a more predictable 3 -wk interval.

Measuring progesterone in milk or blood is the gold standard for defining patterns of estrous cyclicity. Estrous cycles can also be monitored by using either pedometers (leg-mounted) or accelerometers (neck- or ear-mounted) that measure the increase in activity during estrus (Stevenson and Britt, 2017; Reith and Hoy, 2018). Increases in activity could be used to define the interval to first estrus postpartum and perhaps length of the estrous cycle (interval between 2 peaks in activity). Although milk or blood progesterone is superior to activity for phenotyping, there are a greater number of activity systems in place on farm compared with milk progesterone systems. Ismael et al. (2015) measured activity using cow neck collars. They estimated that the heritability of calving to first high activity (CFHA) was 0.16. The heritabilities of estrus duration (ED) and estrus "strength" (ES) were considerably lower (0.02 and 0.05, respectively). The genetic correlation between calving to first insemination and CFHA was extremely high (0.96), and subsequent work from the same authors has confirmed this result (Ismael et al., 2017). 


\section{A}

Normal cycles
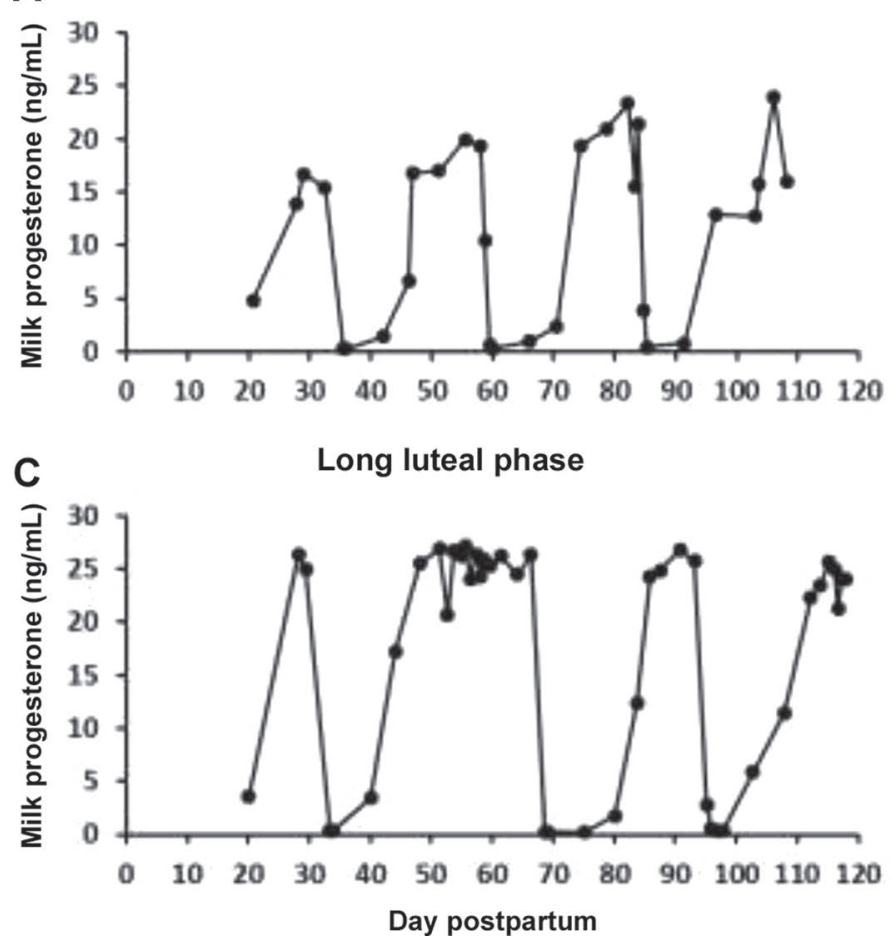
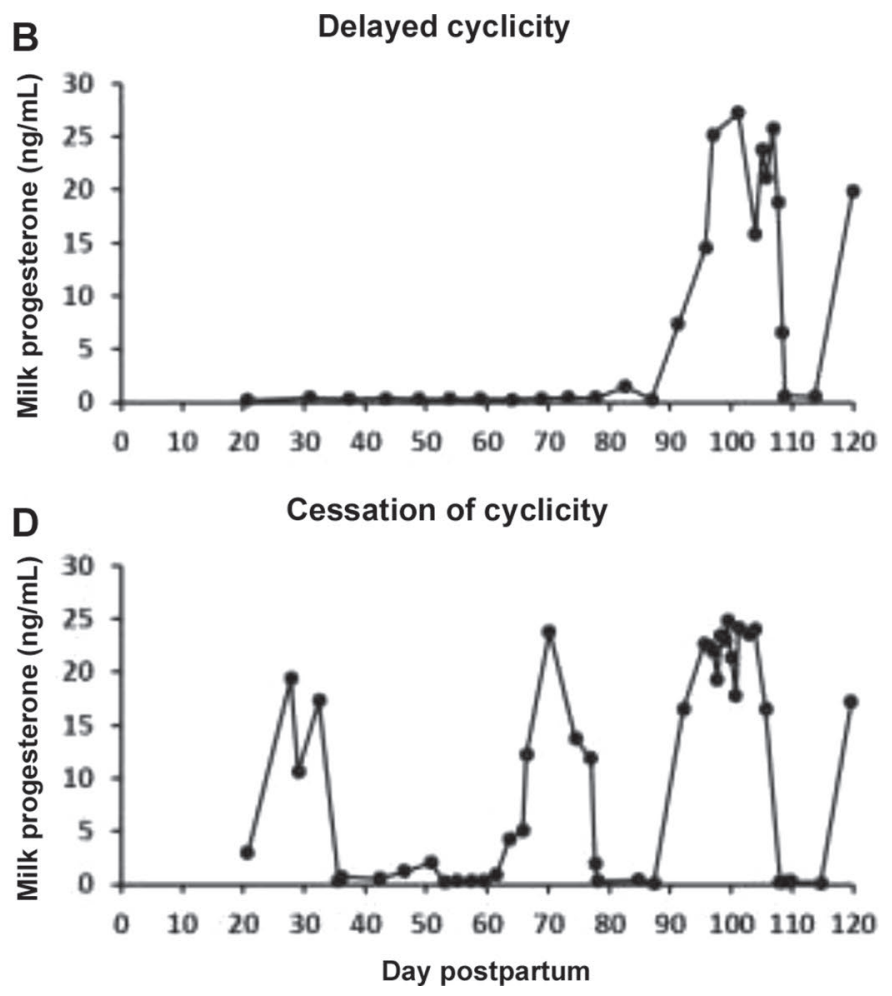

Figure 4. Data from individual cows for milk progesterone during the first $120 \mathrm{~d}$ postpartum measured by Herd Navigator (DeLaval; Tumba, Sweden). Four different progesterone profiles are shown: (A) normal cyclicity (cycles of approximately $20 \mathrm{~d}$ beginning at $20 \mathrm{~d}$ postpartum); (B) delayed cyclicity (interval to first progesterone increase after $56 \mathrm{~d}$ postpartum); (C) prolonged luteal phase (high progesterone for $>20 \mathrm{~d}$ during an estrous cycle; see d 35 to 70 of depicted profile); and (D) cessation of cyclicity (initiation of cycles followed by absence of cyclicity for at least 14 d; see d 35 to 60 of depicted profile).

\section{Estrus Expression}

Estrus is used to determine the time of insemination (Saacke et al., 2000) and depends on circulating estradiol concentrations and the sensitivity of behavioral centers to estradiol (Woelders et al., 2014). Selecting for estrus expression may increase the capacity of the preovulatory follicle to synthesize and secrete estradiol (increase entry rate), decrease the capacity of the cow to metabolize estradiol (reduce clearance rate), and (or) increase the sensitivity of the cow to estradiol (receptor-mediated mechanism). Selecting for DO places considerable pressure on estrus expression when TAI is not used. Cows in estrus become more active and the increase in activity above baseline can be used to identify cows in estrus (Stevenson and Britt, 2017; Reith and Hoy, 2018). Ismael et al. (2015) measured activity using cow neck collars and estimated the heritability of ED and ES as 0.02 and 0.05 , respectively. The 2 activity traits (ED and ES) were correlated with one another and negatively correlated with CFHA. Selecting cows for a shorter interval to first high activity postpartum, therefore, will increase the intensity and duration of estrus expression measured by using activity collars.
López-Gatius et al. (2005) reported greater conception rate in cows that walked more when in estrus. Selecting for ED and ES may therefore increase conception rate.

\section{Silent Ovulation}

Phenotyping cows for estrus expression based on either activity or number of mounts does not address the need to eliminate cows that ovulate but do not show overt signs of estrus (silent ovulation). In their study that employed neck-mounted activity monitors, pressure-sensitive tailhead mount detectors, and frictionactivated tailhead patches, Sauls et al. (2017) reported that approximately $30 \%$ of cows did not express estrus. Regardless of the system used, approximately $70 \%$ of the cows that failed to express estrus had ovulated. The collective interpretation is that $20 \%$ of cows in the study had ovulated without an overt sign that could be detected by measuring either activity or standing behavior.

Phenotyping estrus by using either activity or standing behavior alone suffers from the same limitation; namely, that a threshold must be set to define an estrus. The threshold is typically some amount of activity 
or number of standing events above baseline (Reith and Hoy, 2018). If the threshold is set too low, the percentage of false-positive events (the cow is not truly in estrus) increases. If the threshold is set too high, then the sensitivity is reduced and there are false-negative events (failure to detect estrus in a cow that is truly in estrus). Progesterone monitoring circumvents this problem because a decrease in progesterone (luteolysis) followed by an increase in progesterone approximately 1 wk later is a definitive indication that the cow has regressed her CL and ovulated a follicle (Blavy et al., 2016). Progesterone monitoring, however, does not define exactly when the cow is in estrus, which is necessary to determine the time of ovulation (Adriaens et al., 2018). Integrating the data from progesterone measurement with data from a second system that identifies overt signs of estrus (either activity or standing events) is the only truly effective way to phenotype true estrus events. These true estrus events can be used to select for cows that express a bona fide estrus with a desired duration and intensity. It will also be possible to select against cows that show signs of estrus but are not in true estrus, and to select against cows that have ovulation without overt signs of estrus.

\section{CHALLENGES, KNOWLEDGE GAPS, AND FUTURE RESEARCH}

Improving the current methods used for genetic selection of fertility will require the dairy industry to overcome challenges with respect to data collection and integration. There is also a need to fill specific knowledge gaps through additional research. A greater understanding of heritability and variation within novel fertility traits and the correlation between traditional and novel fertility traits is needed.

\section{Challenges}

Precision farming has led to the on-farm collection of large amounts of data in an inexpensive manner. Although a large amount of data exist on dairy farms, capturing the data from diverse commercial platforms and integrating the information into genetic selection programs create challenges that need to be overcome. This is true for the many commercially available activity systems, the DeLaval Herd Navigator System (Figure 4), and for BCS data from BCS cameras (Figure 2). In most cases, the equipment and software are proprietary so industry cooperation is necessary to capture the information. It will also be necessary to verify that raw data arising from different systems (e.g., legmounted versus neck- or ear-mounted activity devices) are comparable. A reference population may need to be recruited from research and commercial herds for the development of reliable phenotypes for estrous traits (Chesnais et al., 2016).

\section{Knowledge Gaps and Future Research}

Milk Progesterone and Other Measurements in Milk. Progesterone in milk is derived from progesterone circulating in the blood. Blood and milk progesterone concentrations are correlated (Roelofs et al., 2006). Progesterone in blood is theoretically beneficial to fertility through its stimulatory effects on the uterus and embryo (Lonergan, 2011; Spencer et al., 2016). The magnitude of progesterone in milk may be associated with greater fertility if progesterone concentrations are limiting to fertility in postpartum cows (Wiltbank et al., 2006). A model for likelihood of insemination success included cycle height (average of 5 highest progesterone measurements) of the progesterone profile as one of the variables (Blavy et al., 2018). Further understanding of the shape and features of milk progesterone profiles (Blavy et al., 2016) and new models for monitoring on-farm progesterone (Adriaens et al., 2018) may enable greater refinement of fertility traits based on milk progesterone concentrations.

Toledo-Alvarado et al. (2018) demonstrated that milk components and physical properties of milk derived from infrared spectra could be used to predict the phase of the estrous cycle and the day of estrus. The use of milk component data derived from milk infrared spectra or metabolites found in milk may provide a mechanism to identify molecules that are associated with fertility in postpartum cows. Unique milk spectra or individual metabolites that are predictive of pregnancy could form the basis for high-throughput phenotyping that could be applied to genetic selection for fertility.

Activity and Mounting Behavior. In addition to the logistical concerns that surround activity data, some basic research questions also need to be answered. Specifically, what is the phenotypic correlation between increases in activity at estrus and mounting or standing that occur at estrus? Although standing when mounted is viewed as the gold standard for estrus expression and can be readily observed by humans, quantifying this behavior (number of mounts accepted, for example) is more problematic because recording devices must be affixed to the tailhead and repeated mounts can dislodge the recording device. Collars do not fall off when cows come into estrus so data are not lost and there is less system maintenance. Although much of our early understanding of estrus was based on the original HeatWatch system from DDX Inc. (Denver, CO; a tailheadmounted, pressure-sensitive recording device; Nebel et al., 2000), the expense of the devices and the additional 


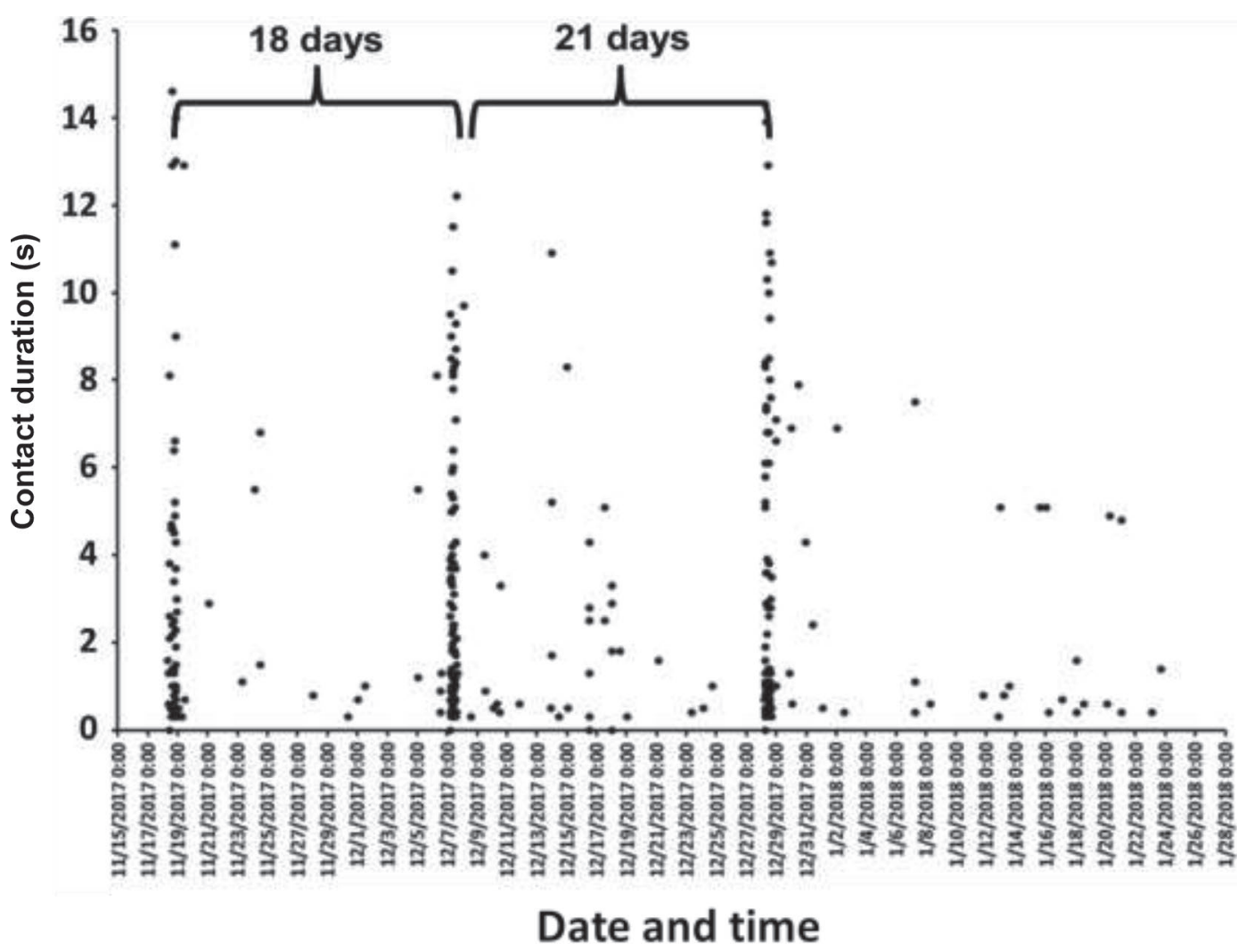

Figure 5. Data collected from a single postpartum cow using a FlashMate Touch Activated in-heat detector (Farmshed Labs, Hamilton, New Zealand) during a 75-d breeding period. The device is placed on the thurl between the hip and pin bones. Each individual dot represents a touch on the device on a specific date and time. The contact duration is reported in seconds ( $\mathrm{y}$-axis). Periods of frequent contact indicating estrus occurred at 18- and 21-d intervals (approximate estrous cycle length). No further contact periods were detected after December 28, indicating that the cow was pregnant or had stopped cycling.

management needed to keep them affixed limited their practicality on farm. We are testing a new system that measures when the cow is mounted (FlashMate Touch Activated in-heat detector; Farmshed Labs, Hamilton, New Zealand; Figure 5). This new system is a standalone system that is considerably less expensive than traditional tail-mounted systems. It could be used to measure the number and duration of mounts that a cow receives and may be suitable for high-throughput phenotyping of estrus traits.

For future dairies, there are perceived advantages to selecting cows that receive a minimum number of mounts when in estrus and selecting cows that become more active when in estrus. Standing behavior is readily observed visually and can be monitored inexpensively with either tailpaint or tailchalk. Activity is easier to automate and less subjective than visually inspecting the tailhead. At least one system objectively measures estrus by reading a tailhead mounted patch (Protrack Heat; Livestock Improvement Corporation, Hamilton, New Zealand). Before intensive selection for estrus expression, it will be necessary to define individual estrus traits and the correlation between those traits. Dobson et al. (2018) recently reported that the increase in activity at estrus peaks near the end of the period of standing to be mounted (Dobson et al., 2018). We do not know the extent to which the increase in activity at estrus is correlated with the number of mounts received by a cow at estrus. If there is sufficient correlation between the traits, then selecting cows for activity should theoretically increase the number of mounts received at estrus.

Genetic selection for estrus behavior (either activity or mounting/standing) should improve the functionality of the ovarian follicle if the primary limitation to estrus expression is the capacity of the follicle to synthesize and secrete adequate estradiol into the circulation. Although estrus expression is desirable for reproductive purposes, there are potential consequences to production and cow health from an overly intense estrus. Cows in estrus will have reduced milk production on the day of estrus, presumably because they are highly active and eat less (Schofield et al., 1991). Likewise, mounting and accepting mounts on slippery concrete surfaces can 
lead to injury if cows fall down. If genetic selection for estrus expression is practiced, then attention should be given to intensity and duration of the event because there are consequences to the cow herself. This situation is not unlike that found in the swine industry, where selection for litter size resulted in the creation of the "highly prolific sow" where $40 \%$ of litters have more live born than teats available for nursing (Kraeling and Webel, 2015). Although this can be managed through cross fostering, it does create management challenges for the industry. In retrospect, selecting for a more uniform litter size would have yielded more useful results. Likewise for dairy, selecting for a uniform estrus intensity and duration is needed.

Estimates of Parameters for Component Selection. There may be value in selecting for individual components of fertility in lieu of DO but at this time, there are insufficient data to estimate which is better, and no long-term studies of component versus direct selection have been conducted. Smith (1967) described the need for estimates of heritability as well as the coefficient of variation when deciding whether selecting on components is superior to direct selection for a "product" trait. They used the example of fleece weight in sheep (a product trait defined by 5 component traits) to demonstrate that the use of an index of components was only slightly better than direct selection for fleece weight. They concluded that index selection might be worthwhile in special situations where large differences exist in the heritability and variation of the component traits and when the traits are highly correlated. Although good data exist for disease traits in dairy cows, most of the components of fertility (Figure 1) and the new traits listed in this review have a limited amount of information with respect to heritability and variation. As explained by Smith (1967), the gains in efficiency from component selection need to be offset by the extra effort needed to measure the individual components. Additional research is necessary, therefore, to estimate specific parameters for fertility traits and determine whether selection for individual components can effect more rapid genetic change in fertility than direct selection for DO. This new information could also be used to model DO with respect to its individual components. This model could then be used to estimate the effect of synchronization programs on DO and the potential impact on overall fertility if these programs were no longer used on dairy farms.

\section{CONCLUSIONS}

Highly fertile cows establish pregnancy sooner after calving and require fewer inseminations than lowerfertility cows. Genetic selection for fertility as practiced today is leading to the rapid improvement in reproductive performance of dairy cattle. Emerging technologies will allow the high-throughput phenotyping of the individual events leading to pregnancy. Refined phenotypes may lead to the creation, evaluation, and implementation of new traits that place selection pressure on estrous cyclicity, estrus expression, and absence of silent ovulation. These new traits will need to be evaluated relative to existing traits to determine whether they provide additional value beyond direct selection for DO. Timed AI programs do not invalidate DO but it is necessary to understand the effect of TAI on the components of DO. Selecting cows for a functional reproductive system may ensure uniform performance of future cows across a variety of reproductive management systems.

\section{ACKNOWLEDGMENTS}

The author thanks William Lamberson of the Division of Animal Sciences University of Missouri for his helpful comments during the preparation and revision of this manuscript.

\section{REFERENCES}

Adriaens, I., W. Saeys, T. Huybrechts, C. Lamberigts, L. François, K. Geerinckx, J. Leroy, B. De Ketelaere, and B. Aernouts. 2018. A novel system for on-farm fertility monitoring based on milk progesterone. J. Dairy Sci. https://doi.org/10.3168/jds.2017-13827.

Bauman, D. E., and W. B. Currie. 1980. Partitioning of nutrients during pregnancy and lactation: A review of mechanisms involving homeostasis and homeorhesis. J. Dairy Sci. 63:1514-1529.

Beagley, J. C., K. J. Whitman, K. E. Baptiste, and J. Scherzer. 2010. Physiology and treatment of retained fetal membranes in cattle. J. Vet. Intern. Med. 24:261-268. https://doi.org/10.1111/j.1939-1676 .2010.0473.x.

Berry, D. P., E. Wall, and J. E. Pryce. 2014. Genetics and genomics of reproductive performance in dairy and beef cattle. Animal 8(Suppl. 1):105-121. https://doi.org/10.1017/S1751731114000743.

Blavy, P., M. Derks, O. Martin, J. K. Höglund, and N. C. Friggens. 2016. Overview of progesterone profiles in dairy cows. Theriogenology 86:1061-1071. https://doi.org/10.1016/j.theriogenology.2016 .03.037.

Blavy, P., N. C. Friggens, K. R. Nielsen, J. M. Christensen, and M. Derks. 2018. Estimating probability of insemination success using milk progesterone measurements. J. Dairy Sci. 101:1648-1660. https://doi.org/10.3168/jds.2016-12453.

Bouquet, A., and J. Juga. 2013. Integrating genomic selection into dairy cattle breeding programmes: A review. Animal 7:705-713. https://doi.org/10.1017/S1751731112002248.

Bowley, F. E., R. E. Green, P. R. Amer, and S. Meier. 2015. Novel approaches to genetic analysis of fertility traits in New Zealand dairy cattle. J. Dairy Sci. 98:2005-2012. https://doi.org/10.3168/ jds.2014-8266.

Bromfield, J. J., J. E. P. Santos, J. Block, R. S. Williams, and I. M. Sheldon. 2015. Physiology and Endocrinology Symposium: Uterine infection: Linking infection and innate immunity with infertility in the high-producing dairy cow. J. Anim. Sci. 93:2021-2033. https:/ /doi.org/10.2527/jas.2014-8496.

Brotzman, R. L., D. Döpfer, M. R. Foy, J. P. Hess, K. V. Nordlund, T. B. Bennett, and N. B. Cook. 2015. Survey of facility and management characteristics of large, Upper Midwest dairy herds clustered 
by Dairy Herd Improvement records. J. Dairy Sci. 98:8245-8261. https://doi.org/10.3168/jds.2014-9264.

Butler, S. T. 2014. Nutritional management to optimize fertility of dairy cows in pasture-based systems. Animal 8(Suppl 1):15-26. https://doi.org/10.1017/S1751731114000834.

Carneiro, L. C., J. G. Cronin, and I. M. Sheldon. 2016. Mechanisms linking bacterial infections of the bovine endometrium to disease and infertility. Reprod. Biol. 16:1-7. https://doi.org/10.1016/j .repbio.2015.12.002.

Carthy, T. R., D. P. Ryan, A. M. Fitzgerald, R. D. Evans, and D. P. Berry. 2015. Genetic parameters of ovarian and uterine reproductive traits in dairy cows. J. Dairy Sci. 98:4095-4106. https://doi .org/10.3168/jds.2014-8924.

Carvalho, P. D., V. G. Santos, J. O. Giordano, M. C. Wiltbank, and P. M. Fricke. 2018. Development of fertility programs to achieve high 21-day pregnancy rates in high-producing dairy cows. Theriogenology 114:165-172. https://doi.org/10.1016/j.theriogenology 2018.03.037.

Cavalieri, J., G. Hepworth, L. A. Fitzpatrick, R. W. Shephard, and K. L. Macmillan. 2006. Manipulation and control of the estrous cycle in pasture-based dairy cows. Theriogenology 65:45-64. https://doi .org/10.1016/j.theriogenology.2005.10.005.

Chesnais, J. P., T. A. Cooper, G. R. Wiggans, M. Sargolzaei, J. E. Pryce, and F. Miglior. 2016. Using genomics to enhance selection of novel traits in North American dairy cattle. J. Dairy Sci. 99:2413-2427. https://doi.org/10.3168/jds.2015-9970.

Cole, J. B., and P. M. VanRaden. 2018. Symposium review: Possibilities in an age of genomics: The future of selection indices. J. Dairy Sci. 101:3686-3701. https://doi.org/10.3168/jds.2017-13335.

Contreras, G. A., C. Strieder-Barboza, and J. De Koster. 2018. Symposium review: Modulating adipose tissue lipolysis and remodeling to improve immune function during the transition period and early lactation of dairy cows. J. Dairy Sci. 101:2737-2752. https://doi .org/10.3168/jds.2017-13340.

Crowe, M. A. 2008. Resumption of ovarian cyclicity in post-partum beef and dairy cows. Reprod. Domest. Anim. 43(Suppl. 5):20-28. https://doi.org/10.1111/j.1439-0531.2008.01210.x.

Dechow, C. D., G. W. Rogers, and J. S. Clay. 2002. Heritability and correlations among body condition score loss, body condition score, production and reproductive performance. J. Dairy Sci. 85:30623070. https://doi.org/10.3168/jds.S0022-0302(02)74393-2.

Dobson, H., J. Williams, J. E. Routly, D. N. Jones, J. Cameron, A. Holman-Coates, and R. F. Smith. 2018. Short communication: Chronology of different sexual behaviors and motion activity during estrus in dairy cows. J. Dairy Sci. https://doi.org/10.3168/jds .2017-14341.

Forde, N., and P. Lonergan. 2017. Interferon-tau and fertility in ruminants. Reproduction 154:F33-F43. https://doi.org/10.1530/REP $-17-0432$.

Fuenzalida, M. J., P. M. Fricke, and P. L. Ruegg. 2015. The association between occurrence and severity of subclinical and clinical mastitis on pregnancies per artificial insemination at first service of Holstein cows. J. Dairy Sci. 98:3791-3805. https://doi.org/10 .3168/jds.2014-8997.

Galvão, K. N., M. Frajblat, W. R. Butler, S. B. Brittin, C. L. Guard, and R. O. Gilbert. 2010. Effect of early postpartum ovulation on fertility in dairy cows. Reprod. Domest. Anim. 45:e207-e211. https://doi.org/10.1111/j.1439-0531.2009.01517.x.

Gilbert, R. O. 2016. Management of reproductive disease in dairy cows. Vet. Clin. North Am. Food Anim. Pract. 32:387-410. https: //doi.org/10.1016/j.cvfa.2016.01.009.

Hansen, T. R., L. D. P. Sinedino, and T. E. Spencer. 2017. Paracrine and endocrine actions of interferon tau (IFNT). Reproduction 154:F45-F59. https://doi.org/10.1530/REP-17-0315.

Hutchison, J. L., P. M. VanRaden, D. J. Null, J. B. Cole, and D. M. Bickhart. 2017. Genomic evaluation of age at first calving. J. Dairy Sci. 100:6853-6861. https://doi.org/10.3168/jds.2016-12060.

Ismael, A., P. Løvendahl, A. Fogh, M. S. Lund, and G. Su. 2017. Improving genetic evaluation using a multitrait single-step genomic model for ability to resume cycling after calving, measured by activity tags in Holstein cows. J. Dairy Sci. 100:8188-8196. https: //doi.org/10.3168/jds.2017-13122.

Ismael, A., E. Strandberg, M. Kargo, A. Fogh, and P. Løvendahl. 2015. Estrus traits derived from activity measurements are heritable and closely related to the time from calving to first insemination. J. Dairy Sci. 98:3470-3477. https://doi.org/10.3168/jds.2014-8940.

Jenkins, G. M., P. Amer, K. Stachowicz, and S. Meier. 2016. Phenotypic associations between gestation length and production, fertility, survival, and calf traits. J. Dairy Sci. 99:418-426. https://doi .org/10.3168/jds.2015-9934.

Johnson, R. K., D. R. Zimmerman, W. R. Lamberson, and S. Sasaki. 1985. Influencing prolificacy of sows by selection for physiological factors. J. Reprod. Fertil. Suppl. 33:139-149.

Komisarek, J., and Z. Dorynek. 2002. Genetic aspects of twinning in cattle. J. Appl. Genet. 43:55-68.

Kraeling, R. R., and S. K. Webel. 2015. Current strategies for reproductive management of gilts and sows in North America. J. Anim. Sci. Biotechnol. 6:3. https://doi.org/10.1186/2049-1891-6-3.

Kuhn, M. T., J. L. Hutchison, and G. R. Wiggans. 2006. Characterization of Holstein heifer fertility in the United States. J. Dairy Sci. 89:4907-4920. https://doi.org/10.3168/jds.S0022-0302(06)72541 $-3$.

Lamming, G. E., and A. O. Darwash. 1998. The use of milk progesterone profiles to characterise components of subfertility in milked dairy cows. Anim. Reprod. Sci. 52:175-190. https://doi.org/10 .1016/S0378-4320(98)00099-2.

Leroy, J. L. M. R., D. Rizos, R. Sturmey, P. Bossaert, A. GutierrezAdan, V. Van Hoeck, S. Valckx, and P. E. J. Bols. 2011. Intrafollicular conditions as a major link between maternal metabolism and oocyte quality: A focus on dairy cow fertility. Reprod. Fertil. Dev. 24:1-12. https://doi.org/10.1071/RD11901.

Lonergan, P. 2011. Influence of progesterone on oocyte quality and embryo development in cows. Theriogenology 76:1594-1601. https: //doi.org/10.1016/j.theriogenology.2011.06.012.

López-Gatius, F., P. Santolaria, I. Mundet, and J. L. Yániz. 2005. Walking activity at estrus and subsequent fertility in dairy cows. Theriogenology 63:1419-1429. https://doi.org/10.1016/j .theriogenology.2004.07.007.

Lucy, M. C. 2001. Reproductive loss in high-producing dairy cattle: Where will it end? J. Dairy Sci. 84:1277-1293. https://doi.org/10 .3168/jds.S0022-0302(01)70158-0.

Lucy, M. C. 2003. Mechanisms linking nutrition and reproduction in postpartum cows. Reprod. Suppl. 61:415-427.

Lucy, M. C. 2007. Fertility in high-producing dairy cows: Reasons for decline and corrective strategies for sustainable improvement. Soc. Reprod. Fertil. Suppl. 64:237-254.

Lucy, M. C., S. T. Butler, and H. A. Garverick. 2014. Endocrine and metabolic mechanisms linking postpartum glucose with early embryonic and foetal development in dairy cows. Animal 8(Suppl. 1):82-90. https://doi.org/10.1017/S1751731114000482.

Lucy, M. C., T. J. Evans, and S. E. Poock. 2016. Lymphocytic foci in the endometrium of pregnant dairy cows: Characterization and association with reduced placental weight and embryonic loss. Theriogenology 86:1711-1719. https://doi.org/10.1016/j.theriogenology .2016.05.030

Lucy, M. C., H. Jiang, and Y. Kobayashi. 2001. Changes in the somatotropin axis associated with the initiation of lactation. J. Dairy Sci. 84(E. Suppl.):E113-E119.

Lucy, M. C., S. McDougall, and D. P. Nation. 2004. The use of hormonal treatments to improve the reproductive performance of lactating dairy cows in feedlot or pasture-based management systems. Anim. Reprod. Sci. 82-83:495-512. https://doi.org/10.1016/ j.anireprosci.2004.05.004.

Lucy, M. C., G. A. Verkerk, B. E. Whyte, K. A. Macdonald, L. Burton, R. T. Cursons, J. R. Roche, and C. W. Holmes. 2009. Somatotropic axis components and nutrient partitioning in genetically diverse dairy cows managed under different feed allowances in a pasture system. J. Dairy Sci. 92:526-539. https://doi.org/10.3168/ jds.2008-1421. 
Macmillan, K., J. P. Kastelic, and M. G. Colazo. 2018. Update on multiple ovulations in dairy cattle. Animals (Basel) 8. https://doi .org/10.3390/ani8050062.

Mallard, B. A., M. Emam, M. Paibomesai, K. Thompson-Crispi, and L. Wagter-Lesperance. 2015. Genetic selection of cattle for improved immunity and health. Jpn. J. Vet. Res. 63(Suppl. 1):S37S44.

Miglior, F., A. Fleming, F. Malchiodi, L. F. Brito, P. Martin, and C. F. Baes. 2017. A 100-year review: Identification and genetic selection of economically important traits in dairy cattle. J. Dairy Sci. 100:10251-10271. https://doi.org/10.3168/jds.2017-12968.

Nebel, R. L., M. G. Dransfield, S. M. Jobst, and J. H. Bame. 2000. Automated electronic systems for the detection of oestrus and timing of AI in cattle. Anim. Reprod. Sci. 60-61:713-723. https://doi .org/10.1016/S0378-4320(00)00090-7.

Neuenschwander, T. F.-O., F. Miglior, J. Jamrozik, O. Berke, D. F. Kelton, and L. R. Schaeffer. 2012. Genetic parameters for producer-recorded health data in Canadian Holstein cattle. Animal 6:571-578. https://doi.org/10.1017/S1751731111002059.

Nyman, S., K. Johansson, D. J. de Koning, D. P. Berry, R. F Veerkamp, E. Wall, and B. Berglund. 2014. Genetic analysis of atypical progesterone profiles in Holstein-Friesian cows from experimental research herds. J. Dairy Sci. 97:7230-7239. https://doi .org/10.3168/jds.2014-7984.

Parker Gaddis, K. L., J. B. Cole, J. S. Clay, and C. Maltecca. 2014 Genomic selection for producer-recorded health event data in US dairy cattle. J. Dairy Sci. 97:3190-3199. https://doi.org/10.3168/ jds.2013-7543.

Petersson, K.-J., H. Gustafsson, E. Strandberg, and B. Berglund 2006. Atypical progesterone profiles and fertility in Swedish dairy cows. J. Dairy Sci. 89:2529-2538. https://doi.org/10.3168/jds S0022-0302(06)72328-1.

Potter, T. L., C. Arndt, and A. N. Hristov. 2018. Short communication: Increased somatic cell count is associated with milk loss and reduced feed efficiency in lactating dairy cows. J. Dairy Sci. https: //doi.org/10.3168/jds.2017-14062.

Pryce, J. E., and B. L. Harris. 2006. Genetics of body condition score in New Zealand dairy cows. J. Dairy Sci. 89:4424-4432. https:// doi.org/10.3168/jds.S0022-0302(06)72490-0.

Pryce, J. E., T. T. T. Nguyen, M. Axford, G. Nieuwhof, and M. Shaffer. 2018. Symposium review: Building a better cow-The Australian experience and future perspectives. J. Dairy Sci. 101:37023713. https://doi.org/10.3168/jds.2017-13377.

Pryce, J. E., K. L. Parker Gaddis, A. Koeck, C. Bastin, M. Abdelsayed, N. Gengler, F. Miglior, B. Heringstad, C. Egger-Danner, K. F. Stock, A. J. Bradley, and J. B. Cole. 2016. Invited review: Opportunities for genetic improvement of metabolic diseases. J. Dairy Sci. 99:6855-6873. https://doi.org/10.3168/jds.2016-10854.

Ranasinghe, R. M. S. B. K., T. Nakao, K. Yamada, K. Koike, A Hayashi, and C. M. B. Dematawewa. 2011. Characteristics of prolonged luteal phase identified by milk progesterone concentrations and its effects on reproductive performance in Holstein cows. J. Dairy Sci. 94:116-127. https://doi.org/10.3168/jds.2010-3213.

Reith, S., and S. Hoy. 2018. Review: Behavioral signs of estrus and the potential of fully automated systems for detection of estrus in dairy cattle. Animal 12:398-407. https://doi.org/10.1017/ S1751731117001975.

Remnant, J. G., M. J. Green, J. N. Huxley, and C. D. Hudson. 2015 Variation in the interservice intervals of dairy cows in the United Kingdom. J. Dairy Sci. 98:889-897. https://doi.org/10.3168/jds $.2014-8366$

Ribeiro, E. S., G. Gomes, L. F. Greco, R. L. A. Cerri, A. Vieira-Neto, P. L. J. Monteiro, F. S. Lima, R. S. Bisinotto, W. W. Thatcher, and J. E. P. Santos. 2016. Carryover effect of postpartum inflammatory diseases on developmental biology and fertility in lactating dairy cows. J. Dairy Sci. 99:2201-2220. https://doi.org/10.3168/ jds.2015-10337.

Ribeiro, E. S., F. S. Lima, L. F. Greco, R. S. Bisinotto, A. P. A. Monteiro, M. Favoreto, H. Ayres, R. S. Marsola, N. Martinez, W. W. Thatcher, and J. E. P. Santos. 2013. Prevalence of periparturient diseases and effects on fertility of seasonally calving grazing dairy cows supplemented with concentrates. J. Dairy Sci. 96:5682-5697. https://doi.org/10.3168/jds.2012-6335.

Richardson, B. N., S. L. Hill, J. S. Stevenson, G. D. Djira, and G. A. Perry. 2016. Expression of estrus before fixed-time AI affects conception rates and factors that impact expression of estrus and the repeatability of expression of estrus in sequential breeding seasons. Anim. Reprod. Sci. 166:133-140. https://doi.org/10.1016/j .anireprosci.2016.01.013.

Roche, J. R., N. C. Friggens, J. K. Kay, M. W. Fisher, K. J. Stafford, and D. P. Berry. 2009. Invited review: Body condition score and its association with dairy cow productivity, health, and welfare. J. Dairy Sci. 92:5769-5801. https://doi.org/10.3168/jds.2009-2431.

Roelofs, J. B., F. J. C. M. Van Eerdenburg, W. Hazeleger, N. M. Soede, and B. Kemp. 2006. Relationship between progesterone concentrations in milk and blood and time of ovulation in dairy cattle. Anim. Reprod. Sci. 91:337-343. https://doi.org/10.1016/j .anireprosci.2005.04.015

Saacke, R. G., J. C. Dalton, S. Nadir, R. L. Nebel, and J. H. Bame. 2000. Relationship of seminal traits and insemination time to fertilization rate and embryo quality. Anim. Reprod. Sci. 60-61:663677.

Sauls, J. A., B. E. Voelz, S. L. Hill, L. G. D. Mendonça, and J. S. Stevenson. 2017. Increasing estrus expression in the lactating dairy cow. J. Dairy Sci. 100:807-820. https://doi.org/10.3168/jds.2016 $-11519$.

Sax, J. K. 2017. Biotechnology and consumer decision-making. Seton Hall Law Rev. 47:433-486.

Schofield, S. A., C. J. C. Phillips, and A. R. Owens. 1991. Variation in the milk production, activity rate and electrical impedance of cervical mucus over the oestrous period of dairy cows. Anim. Reprod. Sci. 24:231-248. https://doi.org/10.1016/S0378-4320(05)80007-7.

Sheldon, I. M., J. G. Cronin, M. Pospiech, and M. L. Turner. 2018 Symposium review: Mechanisms linking metabolic stress with innate immunity in the endometrium. J. Dairy Sci. 101:3655-3664. https://doi.org/10.3168/jds.2017-13135.

Shorten, P. R., M. Donnison, R. M. McDonald, S. Meier, A. M. Ledgard, and D. Berg. 2018. A mathematical model of in vivo bovine blastocyst developmental to gestational Day 15. J. Dairy Sci. https://doi.org/10.3168/jds.2017-14306.

Smith, C. 1967. A note on the improvement of a trait by selecting on its components. Anim. Prod. 9:127-130. https://doi.org/10.1017/ S0003356100038356.

Spencer, T. E., N. Forde, and P. Lonergan. 2016. The role of progesterone and conceptus-derived factors in uterine biology during early pregnancy in ruminants. J. Dairy Sci. 99:5941-5950. https://doi .org/10.3168/jds.2015-10070.

Sterry, R. A., M. L. Welle, and P. M. Fricke. 2006. Treatment with gonadotropin-releasing hormone after first timed artificial insemination improves fertility in noncycling lactating dairy cows. J. Dairy Sci. 89:4237-4245. https://doi.org/10.3168/jds.S0022 $-0302(06) 72469-9$.

Stevenson, J. S., and J. H. Britt. 2017. A 100-year review: Practical female reproductive management. J. Dairy Sci. 100:10292-10313. https://doi.org/10.3168/jds.2017-12959.

Sturman, H., E. A. Oltenacu, and R. H. Foote. 2000. Importance of inseminating only cows in estrus. Theriogenology 53:1657-1667. https://doi.org/10.1016/S0093-691X(00)00305-8.

Tenghe, A. M. M., A. C. Bouwman, B. Berglund, E. Strandberg, J. Y Blom, and R. F. Veerkamp. 2015. Estimating genetic parameters for fertility in dairy cows from in-line milk progesterone profiles. J. Dairy Sci. 98:5763-5773. https://doi.org/10.3168/jds.2014-8732.

Tenghe, A. M. M., A. C. Bouwman, B. Berglund, E. Strandberg, D. J. de Koning, and R. F. Veerkamp. 2016. Genome-wide association study for endocrine fertility traits using single nucleotide polymorphism arrays and sequence variants in dairy cattle. J. Dairy Sci. 99:5470-5485. https://doi.org/10.3168/jds.2015-10533.

Thomasen, J. R., A. Willam, C. Egger-Danner, and A. C. Sørensen. 2016. Reproductive technologies combine well with genomic selection in dairy breeding programs. J. Dairy Sci. 99:1331-1340. https: //doi.org/10.3168/jds.2015-9437. 
Toledo-Alvarado, H., A. I. Vazquez, G. de los Campos, R. J. Tempelman, G. Gabai, A. Cecchinato, and G. Bittante. 2018. Changes in milk characteristics and fatty acid profile during the estrous cycle in dairy cows. J. Dairy Sci. 101:9135-9153. https://doi.org/ 10.3168/jds.2018-14480.

VanRaden, P. M., A. H. Sanders, M. E. Tooker, R. H. Miller, H. D. Norman, M. T. Kuhn, and G. R. Wiggans. 2004. Development of a national genetic evaluation for cow fertility. J. Dairy Sci. 87:22852292. https://doi.org/10.3168/jds.S0022-0302(04)70049-1.

Vukasinovic, N., N. Bacciu, C. A. Przybyla, P. Boddhireddy, and S. K. DeNise. 2017. Development of genetic and genomic evaluation for wellness traits in US Holstein cows. J. Dairy Sci. 100:428-438. https://doi.org/10.3168/jds.2016-11520.

Wagener, K., C. Gabler, and M. Drillich. 2017. A review of the ongoing discussion about definition, diagnosis and pathomechanism of subclinical endometritis in dairy cows. Theriogenology 94:21-30. https://doi.org/10.1016/j.theriogenology.2017.02.005.

Wiltbank, M., H. Lopez, R. Sartori, S. Sangsritavong, and A. Gümen. 2006. Changes in reproductive physiology of lactating dairy cows due to elevated steroid metabolism. Theriogenology 65:17-29. https://doi.org/10.1016/j.theriogenology.2005.10.003.
Wiltbank, M. C., G. M. Baez, A. Garcia-Guerra, M. Z. Toledo, P. L. J. Monteiro, L. F. Melo, J. C. Ochoa, J. E. P. Santos, and R. Sartori. 2016. Pivotal periods for pregnancy loss during the first trimester of gestation in lactating dairy cows. Theriogenology 86:239-253. https://doi.org/10.1016/j.theriogenology.2016.04.037.

Wiltbank, M. C., P. M. Fricke, S. Sangsritavong, R. Sartori, and O. J. Ginther. 2000. Mechanisms that prevent and produce double ovulations in dairy cattle. J. Dairy Sci. 83:2998-3007. https://doi .org/10.3168/jds.S0022-0302(00)75201-5.

Wiltbank, M. C., A. Gümen, and R. Sartori. 2002. Physiological classification of anovulatory conditions in cattle. Theriogenology $57: 21-52$

Wiltbank, M. C., and J. R. Pursley. 2014. The cow as an induced ovulator: Timed AI after synchronization of ovulation. Theriogenology 81:170-185. https://doi.org/10.1016/j.theriogenology.2013.09.017.

Woelders, H., T. van der Lende, A. Kommadath, M. F. W. te Pas, M. A. Smits, and L. M. T. E. Kaal. 2014. Central genomic regulation of the expression of oestrous behaviour in dairy cows: A review. Animal 8:754-764. https://doi.org/10.1017/S1751731114000342. 